\title{
MEMPREDIKSI FINANCIAL DISTRESS PADA PERUSAHAAN SEKTOR TEKSTIL DAN GARMENT YANG TERDAFTAR DI BEI
}

\author{
Oleh : \\ Maria Hendriani, \\ Program Studi Akuntansi, STIE DR. KHEZ Muttaqien \\ mariahendriani@gmail.com \\ Dean Subhan Saleh, \\ Program Studi Akuntansi, STIE DR. KHEZ Muttaqien \\ deansubhansaleh@gmail.com \\ Rika Kartika, \\ Program Studi Akuntansi, STIE DR. KHEZ Muttaqien \\ Rikakrtk11@gmail.com
}

Article Info
Article History :
Received 13 Sept - 2021
Accepted 25 Sept - 2021
Available Online 25 Sept-
2021

Keyword :

Current Ratio, Enterprise Risk Management, Labor

Cost, Financial Distress.

\begin{abstract}
The prospect of the textile and garment sector in Indonesia is predicted to continue to decline since the last few years. The purpose of this study is to predict financial difficulties in textile and garment sector companies listed on the Indonesia Stock Exchange in 2016-2018. The independent variables used in this study are Current Ratio, Enterprise Risk Management, and Labor Costs. The Financial Distress model used in this study is the Altman $Z$ score. This research data was obtained from the Indonesia Stock Exchange for the period 2016-2018. The sample used in this study were 12 textile and garment sector companies with saturated sampling method. The analysis technique used in this research is panel data regression. The results showed that the Current Ratio had a positive and significant effect on predicting Financial Distress, the proportion of Enterprise Risk Management had no significant effect on predicting Financial Distress, and Labor Costs had a significant negative effect on predicting Financial Distress.
\end{abstract}




\section{PENDAHULUAN}

Persaingan dunia ekonomi saat ini semakin ketat dan semakin kuat. Hal ini dapat berpengaruh pada perkembangan perekonomian secara nasional maupun internasional. Salah satu dampaknya adalah biaya yang akan dikeluarkan oleh perusahaan akan semakin tinggi, sehingga akan mempengaruhi kinerja perusahaan. Jika suatu perusahaan tidak sanggup bersaing maka perusahaan tersebut akan mengalami kerugian, yang pada akhirnya bisa membuat suatu perusahaan mengalami Financial Distress, tak terkecuali pada perusahaan sektor tekstil dan garment.

Prospek sektor tekstil dan garment di indonesia di prediksi masih mengalami penurunan sejak beberapa tahun terakhir. Hal ini terjadi karena banyaknya pesaing yang berasal dari negara asing terutama produkproduk buatan Negara Cina. Kelangsungan operasional penjualan perusahaan di pasar domestik menjadi tidak stabil karena banyaknya produk tekstil dari China. Kekhawatiran ini beralasan karena harga produk mereka jauh di bawah harga tekstil dalam negeri dan dan kualitasnya tidak kalah bagusnya.

\section{Sumber : www.cnbcindonesia.com (data diolah} 2019)

\section{Gambar 1.1 \\ Grafik Impor Tekstil Dari China Tahun 2016-2018}

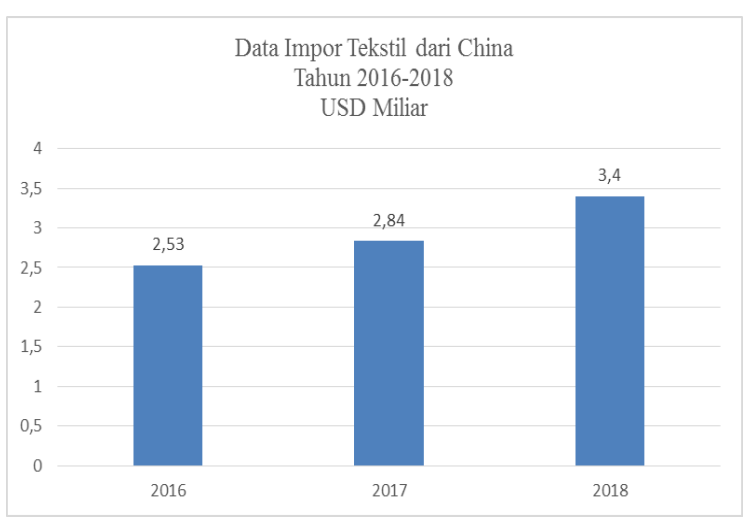

Dari tahun 2017 ke tahun 2018 terdapat kenaikan yang cukup tinggi, hal ini terjadi karena Peraturan Menteri Perdagangan No 64
Tahun 2017 tentang ketentuan impor. Dimana peraturan tersebut menjadi akar masalah dari banjirnya impor tekstil. Dengan hantaman produk impor yang terjadi secara terus menerus maka dapat menyebabkan sejumlah industri mengalami kesulitan dalam menjalankan usahanya dan dapat menyebabkan kebangkrutan (Financial Distress). Sebagai contoh, isu tentang perusahaan mengalami kesulitan dalam menjalankan usahanya yaitu PT. Argo Pantes Tbk dalam beberapa tahun terakhir ini mengalami penurunan laba. Tercatat pada tahun 2016 mengantongi laba sebesar US\$ 25,71 juta, tahun 2017 memperoleh laba sebesar US\$ 14,87 juta, dan pada tahun 2018 menghasilkan laba US\$ 8,18 juta. Penurunan ini disebakan oleh hantaman produk impor dari China yang semakin banyak masuk ke dalam negeri. Salah satu tanda kemungkinannya terjadi Financial Distress adalah adanya penurunan laba selama 3 tahun berturut-turut.

Financial Distress merupakan kondisi perusahaan yang cenderung mengalami kesulitan likuiditas, terbukti dengan menurunnya kemampuan perusahaan dalam memenuhi kewajiban kepada kreditur (Hanifah, 2013 dalam jurnal Frizka Fadilla dkk, 2019). Kondisi ini biasanya ditandai dengan penurunan kualitas produk, keterlambatan pengiriman dan keterlambatan pembayaran tagihan bank. Diharapkan jika kesulitan keuangan diketahui sejak awal, dapat diambil langkah-langkah untuk memperbaiki keadaan, sehingga perusahaan dapat terhindar dari kesulitan yang lebih berat seperti likuidasi atau kebangkrutan (Mamang Hariyanto, 2018). Salah satu indikator yang dapat menggambarkan kemampuan perusahaan dalam memenuhi kewajiban jangka pendeknya (utang) adalah rasio likuiditas. Rasio likuiditas yang digunakan dalam penelitian ini adalah Current Ratio.

Hasil penelitian Muhamad Iksan Sopian, dkk.(2019) memberikan bukti empiris bahwa Current Ratio berpengaruh tetapi tidak signifikan terhadap Financial Distress. Sedangkan menurut Imam Asfali (2019) membuktikan bahwa Current Ratio berpengaruh signifikan terhadap Financial Distress. Ketika rasio likuiditas tinggi, perusahaan mampu memenuhi kewajiban jangka pendeknya, tetapi ketika rasio likuiditas rendah, perusahaan tidak mampu untuk memenuhi kewajiban jangka pendeknya. Jika 
suatu perusahaan tidak dapat memenuhi kewajiban jangka pendeknya, maka perusahaan tersebut dapat di indikasikan mengalami kesulitan keuangan (Financial Distress). Untuk menghindari situasi kesulitan keuangan, maka perusahaan harus bisa menentukan strategi bisnis yang tepat.

Memilih strategi bisnis sangat penting dalam menilai risiko, salah satunya dengan Enterprise Risk Management (ERM). ERM adalah proses yang sistematis dan berkesinambungan yang dirancang dan dilaksanakan oleh manajemen untuk memberikan keyakinan yang memadai bahwa setiap risiko yang berpotensi menimbulkan dampak negatif dikelola dengan cara yang sepadan dengan tingkat risiko yang siap diambil oleh perusahaan (Hery, 2015 dalam jurnal Nolita dan Tiara, 2019). Selain strategi bisnis yang tepat, manajemen risiko juga penting dalam mencapai tujuan perusahaan. Semakin baik perusahaan mengelola risiko, maka semakin bagus perusahaan tersebut. Karena jika perusahaan tidak mampu mengelola risiko dengan baik maka perusahaan akan mengalami kondisi Financial Distress. Selain itu kondisi kesulitan keuangan (Financial Distress) biasanya ditandai dengan pengurangan tenaga kerja.

Tenaga kerja merupakan hal yang dibutuhkan sejak awal berdirinya perusahaan, menjalankan produksi, bahkan hingga produk tersebut dipasarkan. Industri tektil dan garment memberikan kontribusi yang cukup besar terhadap pertumbuhan ekonomi, karena mampu menciptakan lapangan kerja yang cukup besar. Namun, kinerja industri tekstil dan garment dalam 3 tahun terakhir ini tidak cukup memuaskan. Beberapa dari perusahaan sektor tekstil dan garment mengalami penurunan laba setiap tahunnya bahkan mengalami kerugian secara terus-menerus. Pasar yang lesu, dan beban biaya tenaga kerja yang terus mengalami kenaikan membuat harga produk menjadi mahal, dan daya beli masyarakat untuk membeli produk tersebut menjadi turun, yang semakin membuat industri sektor tekstil dan garment semakin terpuruk. Hasil penelitian Dean Subhan Saleh (2018) menyatakan bahwa biaya variabel berpengaruh dalam memprediksi terjadinya kondisi Financial Distress. Dengan demikian, saat ini banyak yang melakukan pengurangan tenaga kerja di sektor tekstil dan garment, disebabkan oleh biaya operasional yang besar yang mengharuskan perusahaan utuk mengurangi tenaga kerjanya. Hal tersebut juga dapat diindikasikan sebagai tanda-tanda perusahaan tersebut sedang mengalami kondisi Financial Distress.

\section{KAJIAN PUSTAKA DAN PENGEMBANGAN HIPOTESIS}

\section{Teori Sinyal (Signaling Theory)}

Teori pensinyalan menjelaskan tentang bagaimana sebuah perusahaan harus bisa memberikan sinyal kepada pengguna laporan keuangan. Sinyal tersebut berupa informasi tentang kondisi perusahaan kepada pemilik ataupun pihak yang berkepentingan. Sinyal tersebut juga dapat berasal dari pengungkapan informasi akuntansi, seperti laporan keuangan tahunan, laporan tentang apa yang telah dilakukan manajemen untuk mencapai keinginan pemilik, atau bahkan dalam bentuk promosi dan informasi lain yang menyatakan bahwa perusahaan tersebut lebih baik daripada perusahaan lain (Susilowati dan Turyanto, 2011 dalam Hikmah Amalia, 2018).

\section{Human Judgement Theory}

Human Judgement Theory menjelaskan bagaimana cara orang-orang menggunakan dan memproses informasi akuntansi terhadap suatu fakta dalam konteks pengambilan keputusan.

\section{Financial Distress}

Financial Distress adalah kondisi perusahaan yang cenderung mengalami kesulitan likuiditas yang ditunjukkan dengan kemampuan perusahaan yang semakin menurun dalam memenuhi kewajiban kepada kreditur (Hanifah, 2013 dalam jurnal Frizka Fadilla dkk, 2019). Persamaan yang diperoleh untuk perusahaan manufaktur (tekstil dan garment) yang sudah go public dengan rumus (Edward I. Altman:1968) adalah :

$$
\begin{aligned}
Z= & 0,717 A+0,874 B+3,107 C+0.420 D+ \\
& 0,998 E
\end{aligned}
$$

\section{Current Ratio}

Menurut Gitman dan Zutter (2015) dalam Febriyan dan Ari (2019) menyatakan bahwa likuiditas sebagai pengukur kemampuan perusahaan untuk memenuhi kewajiban jangka pendeknya yang jatuh tempo. Likuiditas juga mengarah kepada neraca suatu perusahaan yang dimana memberikan informasi perusahaan mengenai kemudahan dalam membayar 
hutangnya. Rumus Current Ratio berdasarkan Gitman dan Zutter (2015) dapat dilihat dibawah ini :

$$
C R=\frac{\text { Aktiva Lancar }}{\text { Utang Lancar }} X 100 \%
$$

\section{Enterprise Risk Management}

Menurut ICAEW (2002) dalam Nolita dan Tiara (2019) risiko adalah situasi di mana terdapat ketidakpastian tentang kemungkinan konsekuensi, baik keuntungan maupun kerugian. Perusahaan tidak dapat menghindari risiko, oleh karena itu harus diambil tindakan untuk mengantisipasi risiko tersebut. Langkahlangkah ini disebut Enterprise Risk Mangement (ERM). ERM diterbitkan oleh Committee of Sponsoring Organizations (COSO) pada bulan September 2004 sebagai proses manajemen risiko perusahaan yang dirancang dan diterapkan di setiap strategi perusahaan untuk mencapai tujuan perusahaan. Proksi yang digunakan untuk mengukur pengungkapan informasi manajemen risiko perusahaan adalah indeks ERM Disclosure, yaitu :

$$
E R M D I=\frac{\sum i j \text { Ditem }}{\sum i j \text { Aditem }}
$$

\section{Biaya Tenaga Kerja}

Biaya tenaga kerja langsung adalah jumlah upah yang dibayarkan kepada tenaga kerja yang secara langsung menangani pengolahan bahan baku menjadi produk jadi ditambah sebagian jam kerja tidak produktif yang normal dan tidak dapat dihindari, seperti waktu istirahat dan sholat (Layna, 2019)

\section{Hipotesis}

Hipotesis yang dikemukakan penulis merupakan pengembangan dari tinjauan pustaka dan kerangka berpikir yang berkaitan dengan Current Ratio (CR), Enterprise Risk Management (ERM), dan Biaya Tenaga Kerja (BTK) dalam memprediksi Financial Distress pada Sektor Tekstil Dan Garment. Hipotesis yang dikemukakan adalah sebagai berikut :
H1 : Current Ratio berpengaruh dalam memprediksi Financial Distress.

$\begin{array}{lll}\mathrm{H} 2 & \begin{array}{l}\text { Enterprise Risk } \\ \text { berpengaruh dalam } \\ \text { Financial Distress. }\end{array} & \begin{array}{l}\text { Management } \\ \text { memprediksi }\end{array}\end{array}$

H3 : Biaya Tenaga Kerja berpengaruh dalam memprediksi Financial Distress.

H4 : Current Ratio, Enterprise Risk Management, dan Biaya Tenaga Kerja berpengaruh dalam memprediksi Financial Distress.

\section{METODE PENELITIAN}

Metode penelitian yang digunakan dalam penelitian ini adalah metode pendekatan kuantitatif. Jenis data yang digunakan adalah data sekunder dan merupakan data cross section dan time series. Data yang digunakan berupa laporan keuangan tahunan Perusahaan Sektor Tekstil dan Garment yang terdaftar di Bursa Efek Indonesia (BEI) Periode 2016-2018. Metode penarikan sampel menggunakan sampel jenuh. Teknik analisis data yang digunakan adalah analisis regresi data panel yang diolah melalui aplikasi eviews 10 .

\section{HASIL PENELITIAN}

\section{Analisis Statistik Deskriptif}

Berdasarkan hasil pengujian yang dilakukan, gambaran umum data dalam penelitian ini dapat dilihat pada tabel berikut :

Tabel 4.1 Hasil Statistik Deskriptif

\begin{tabular}{lcccc}
\hline \hline & FD & CR & ERM & BTK \\
\hline \hline Mean & 1.302938 & 178.9013 & 20.83333 & 71758.25 \\
Median & 1.269349 & 132.4008 & 19.90741 & 58554.50 \\
Maximum & 2.753109 & 645.6905 & 33.33333 & 244681.0 \\
Minimum & 0.195304 & 0.088488 & 12.03704 & 1349.000 \\
Std. Dev. & 0.698969 & 150.1141 & 6.777084 & 59926.91 \\
Skewness & 0.239602 & 1.226332 & 0.608573 & 0.944991 \\
Kurtosis & 2.640202 & 4.028925 & 2.189591 & 3.434546 \\
& & & & \\
Jarque-Bera & 0.538636 & 10.61136 & 3.207313 & 5.641294 \\
Probability & 0.763900 & 0.004963 & 0.201160 & 0.059567 \\
& & & & \\
Sum & 46.90576 & 6440.448 & 750.0000 & 2583297. \\
Sum Sq. Dev. & 17.09950 & 788698.8 & 1607.510 & $1.26 \mathrm{E}+11$ \\
Observations & 36 & & & \\
\multicolumn{2}{c}{ Sumber $:$ Hasil Olahan Data Eviews 10} &
\end{tabular}

Sumber : Hasil Olahan Data Eviews 10

Berdasarkan tabel hasil hasil statistik deskriptif diatas, dapat dijelaskan sebagai berikut :

\section{Variabel $\mathrm{Y}=$ Financial Distress $(\mathrm{FD})$}

Dari tabel 4.1 menunjukkan bahwa rata-rata (mean) dari variabel dependen Financial Distress (FD) pada periode 2016-2018 sebesar 1.302938, dengan nilai standar deviasi 
0.698969 lebih kecil dibandingkan nilai ratarata, maka nilai rata-rata tersebut merupakan parameter yang tepat untuk mewakili semua data. Nilai Financial Distress (FD) tertinggi adalah 2.753109 yang dimiliki oleh Perusahaan Argo Pantes Tbk (2016), sedangkan nilai terendah adalah 0.195304 yang dimililki oleh Perusahaan Eratex Djaja Tbk (2018).

\section{Variabel $\mathrm{X}_{1}=$ Current Ratio $(\mathrm{CR})$}

Dari tabel 4.1 menunjukkan bahwa ratarata (mean) dari variabel independen $\mathrm{X}_{1}$ yaitu Current Ratio (CR) pada periode 2016-2018 sebesar 178.9013, dengan nilai standar deviasi 150.1141, lebih kecil dibandingkan nilai ratarata, maka nilai rata-rata tersebut merupakan parameter yang tepat untuk mewakili semua data. Nilai Current Ratio (CR) tertinggi adalah 645.6905 yang dimiliki oleh PT Pan Brothers Tbk (2018). Sedangkan Current Ratio (CR) terendah adalah 0.088488 yang dimilki oleh Perusahaan Indorama Synthetics Tbk (2016).

\section{Variabel $\mathrm{X}_{2}=$ Enterprise Risk Management (ERM)}

Dari tabel 4.1 menunjukkan bahwa ratarata (mean) dari variabel independen $\mathrm{X}_{2}$ yaitu Enterprise Risk Management (ERM) pada periode 2016-2018 sebesar 20.83333, dengan nilai standar deviasi 6.777084 , lebih kecil dibandingkan nilai rata-rata, maka nilai ratarata tersebut merupakan parameter yang tepat untuk mewakili semua data. nilai Enterprise Risk Management (ERM) tertinggi adalah 33.33333 yang dimiliki oleh PT Sri Rejeki Isman Tbk (2016-2018). Sedangkan Enterprise Risk Management (ERM) terendah adalah 12.03704 yang dimilki oleh PT Pan Brothers Tbk (2016-2018).

\section{Variabel $X_{3}=$ Biaya Tenaga Kerja $(B T K)$}

Dari tabel 4.1menunjukkan bahwa ratarata (mean) dari variabel independen $\mathrm{X}_{3}$ yaitu Biaya Tenaga Kerja (BTK) pada periode 20162018 sebesar 71758.25, dengan nilai standar deviasi 59926.91, lebih kecil dibandingkan nilai rata-rata, maka nilai rata-rata tersebut merupakan parameter yang tepat untuk mewakili semua data. Nilai Biaya Tenaga Kerja (BTK) tertinggi adalah 244681.0 yang dimiliki oleh PT Asia Pacific Investama Tbk (2018). Sedangkan Biaya Tenaga Kerja (BTK) terendah adalah 1349.000 yang dimilki oleh Perusahaan Nusantara Inti Corpora Tbk (2017).

\section{Penentuan Model Regresi Data Panel}

\section{Uji Chow}

Chow test merupakan pengujian untuk menentukan model apakah Common Effect Model (CEM) ataukah Fixed Effect Model (FEM) yang paling tepat digunakan dalam mengestimasi data panel.

\section{Tabel 4.2}

\section{Hasil Uji Chow}

Redundant Fixed Effects Tests

Pool: ID

Test period fixed effects

\begin{tabular}{lrrr}
\hline \hline Effects Test & Statistic & d.f. & Prob. \\
\hline \hline Period F & 0.073869 & $(2,30)$ & 0.9290 \\
Period Chi-square & 0.176851 & 2 & 0.9154 \\
\hline \hline
\end{tabular}

Sumber : Hasil Olahan Data Eviews 10

Berdasarkan tabel 4.2 diatas menunjukan bahwa nilai probabilitias Cross-section $F$ adalah sebesar 0.9290 lebih besar dari $a=0,05$. Maka dapat disimpulkan jika data dalam penelitian ini model estimasi yang terpilih adalah Common Effects Model (CEM). Selanjutnya penelitian ini harus melakukan Uji Hausman untuk menentukan model yang terbaik diantara Fixed Effect Model (FEM) dan Random Effect Model (REM).

\section{Uji Hausman}

Hausman test adalah pengujian statistik untuk memilih apakah Fixed Effect Model (FEM) atau Random Effect Model (REM) yang paling tepat digunakan.

\section{Tabel 4.3}

Hasil Uji Hausman

Correlated Random Effects - Hausman Test Pool: ID

Test cross-section random effects

\begin{tabular}{lccc}
\hline \hline Test Summary & $\begin{array}{c}\text { Chi-Sq. } \\
\text { Statistic }\end{array}$ & $\begin{array}{r}\text { Chi-Sq. } \\
\text { d.f. }\end{array}$ & Prob. \\
\hline \hline Cross-section random & 2.035419 & 2 & 0.3614 \\
\hline \hline
\end{tabular}

Sumber : Hasil Olahan Data Eviews 10

Berdasarkan tabel 4.3 diatas menunjukan bahwa nilai probabilitias Cross-section random adalah sebesar 0.3614 lebih besar dari $a=0,05$. Maka dapat disimpulkan jika data dalam penelitian ini yaitu model estimasi yang terpilih adalah Random Effects Model (REM). 


\section{Uji Lagrange Multiplier}

Lagrange Multiplier test merupakan pengujian untuk menentukan model manakah yang lebih tepat digunakan antara Common Effects Model (CEM) dan Random Effect Model (REM) yang paling tepat digunakan dalam mengestimasi data panel.

Tabel 4.4

\section{Hasil Lagrange Multiplier}

Lagrange Multiplier Tests for Random Effects Null hypotheses: No effects

Alternative hypotheses: Two-sided (Breusch-Pagan) and one-sided (all others) alternatives

\begin{tabular}{|c|c|c|c|}
\hline & \multicolumn{3}{|c|}{ Test Hypothesis } \\
\hline & section & Time & Both \\
\hline Breusch-Pagan & $\begin{array}{l}27.15310 \\
(0.0000)\end{array}$ & $\begin{array}{l}1.451533 \\
(0.2283)\end{array}$ & $\begin{array}{l}28.60464 \\
(0.0000)\end{array}$ \\
\hline Honda & $\begin{array}{l}5.210864 \\
(0.0000)\end{array}$ & $\begin{array}{c}-1.204796 \\
(0.8859)\end{array}$ & $\begin{array}{l}2.832718 \\
(0.0023)\end{array}$ \\
\hline King-Wu & $\begin{array}{l}5.210864 \\
(0.0000)\end{array}$ & $\begin{array}{c}-1.204796 \\
(0.8859)\end{array}$ & $\begin{array}{l}0.935618 \\
(0.1747)\end{array}$ \\
\hline Standardized Honda & $\begin{array}{l}6.285828 \\
(0.0000)\end{array}$ & $\begin{array}{c}-0.980737 \\
(0.8366)\end{array}$ & $\begin{array}{l}0.626919 \\
(0.2654)\end{array}$ \\
\hline Standardized King-Wu & $\begin{array}{l}6.285828 \\
(0.0000)\end{array}$ & $\begin{array}{c}-0.980737 \\
(0.8366)\end{array}$ & $\begin{array}{c}-0.994322 \\
(0.8400)\end{array}$ \\
\hline Gourieroux, et al.* & -- & -- & $\begin{array}{l}27.15310 \\
(0.0000)\end{array}$ \\
\hline
\end{tabular}

Sumber : Hasil Olahan Data Eviews 10

Berdasarkan tabel 4.4 diatas menunjukan bahwa nilai $\mathrm{P}$ value sebesar 0.0000 dimana nilai tersebut kurang dari $a=0,05$. Maka dapat disimpulkan jika data dalam penelitian ini yaitu model estimasi yang terpilih adalah Random Effects Model (REM).

\section{Uji Normalitas}

Uji normalitas ini bertujuan untuk mengkaji apakah nilai residual berdistribusi normal atau tidak.

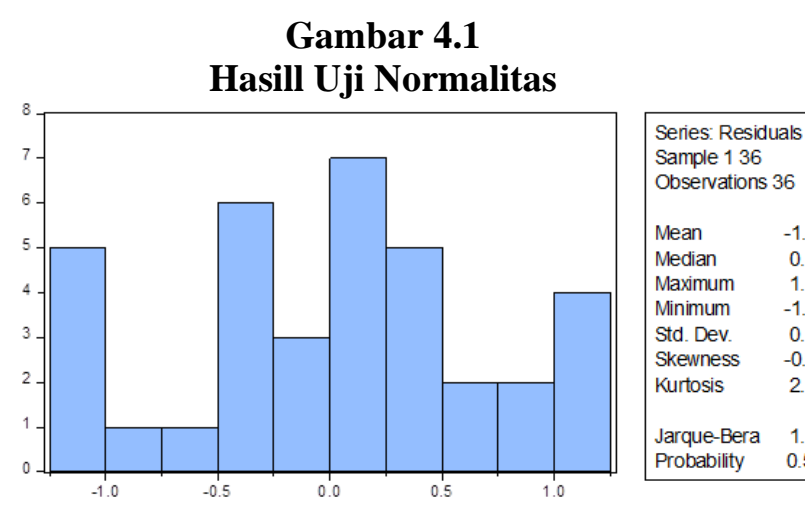

Sumber : Hasil Olahan Data Eviews 10

Berdasarkan gambar 4.1 diatas menunjukan bahwa nilai Jarque-Bera adalah sebesar 1.172403 dengan probability 0.556437 , dimana probabilitias lebih besar dari $a=0,05$.
Maka dapat disimpulkan jika data dalam penelitian ini berdistribusi normal dan memenuhi syarat dalam uji normalitas data.

\section{Uji Heteroskedastisitas}

Uji Heteroskedastisitas ini bertujuan untuk mengetahui apakah dalam model regresi terdapat kesamaan varians dari residual satu pengamatan ke pengamatan yang lain.

Tabel 4.5

Hasil Uji Heteroskedastisitas

Heteroskedasticity Test: Glejser

\begin{tabular}{llll}
\hline \hline F-statistic & 2.567811 & Prob. F(3,32) & 0.0717 \\
Obs*R-squared & 6.984877 & Prob. Chi-Square(3) & 0.0724 \\
Scaled explained SS & 5.689468 & Prob. Chi-Square(3) & 0.1277
\end{tabular}

Sumber : Hasil Olahan Data Eviews 10

Berdasarkan tabel 4.5 diatas menunjukan bahwa nilai Prob. Chi-Square dari $O b s^{*} R$ squared adalah sebesar 0,0724 lebih besar dari nilai $a=0,05$. Maka dapat disimpulkan bahwa dalam model ini tidak terjadi heteroskedastisitas.

\section{Uji Multikolinearitas}

Uji Multikolinearitas diperlukan untuk menguji apakah dalam model regresi ditemukan adanya korelasi antar variabel independen dimana regresi yang baik tidak terjadi ortogonal. Model regresi yang bebas multikolinearitas adalah Mempunyai nilai VIP $<$ dari 10, sedangkan untuk angka toleransi mendekati 1.

Tabel 4.6

Hasil Uji Multikolinearitas

\begin{tabular}{cccc} 
Variable & $\begin{array}{c}\text { Coefficient } \\
\text { Variance }\end{array}$ & $\begin{array}{c}\text { Uncentered } \\
\text { VIF }\end{array}$ & $\begin{array}{c}\text { Centered } \\
\text { VIF }\end{array}$ \\
\hline \hline & & & \\
CR & $7.46 \mathrm{E}-07$ & 3.073796 & 1.249057 \\
ERM & 0.000295 & 10.79512 & 1.007007 \\
BTK & $4.68 \mathrm{E}-12$ & 3.094571 & 1.250431 \\
$\mathrm{C}$ & 0.177542 & 13.57737 & NA \\
\hline \hline
\end{tabular}

Sumber : Hasil Olahan Data Eviews 10

Berdasarkan tabel 4.6 diatas menunjukan bahwa nilai centered VIF ketiga variabel lebih kecil dari 10. Maka dapat disimpulkan bahwa dalam model ini tidak terjadi multikolinearitas.

\section{Uji Autokorelasi}

Autokorelasi yaitu dengan menggunakan Uji Langrange-Multiplier. Autokorelasi merupakan korelasi antara anggota observasi 
yang disusun menurut waktu dan tempat. Model regresi yang baik seharusnya tidak terjadi autokorelasi

\section{Tabel 4.7}

Hasil Uji Autokorelasi

Breusch-Godfrey Serial Correlation LM Test:

$\begin{array}{llll}\text { F-statistic } & 0.395638 & \text { Prob. F(2,29) } & 0.6768 \\ \text { Obs*R-squared } & 0.929624 & \text { Prob. Chi-Square(2) } & 0.6283\end{array}$

Sumber : Hasil Olahan Data Eviews 10

Berdasarkan tabel 4.7 Diatas menunjukan bahwa nilai Prob. Chi-Square dari Obs*Rsquared adalpah sebesar 0.6283 yakni lebih besar dari nilai $a=0,05$. Maka dapat disimpulkan dalam model penelitian ini tidak mengandung autokorelasi.

\section{Analisis Regresi Data Panel}

Berdasarkan hasil dari penentuan model regresi data panel yang terdiri dari Uji Chow dan Uji Lagrange Multiplier (LM) yang telah dilakukan maka model yang terplilih yaitu Random Effect Model (REM).

Tabel 4.8

\section{Hasil Uji Regresi Data Panel (Random Effect Model-REM)}

Dependent Variable: FD?

Method: Pooled EGLS (Cross-section random effects)

Date: 10/06/20 Time: 13:43

Sample: 13

Included observations: 3

Cross-sections included: 12

Total pool (balanced) observations: 36

Swamy and Arora estimator of component variance

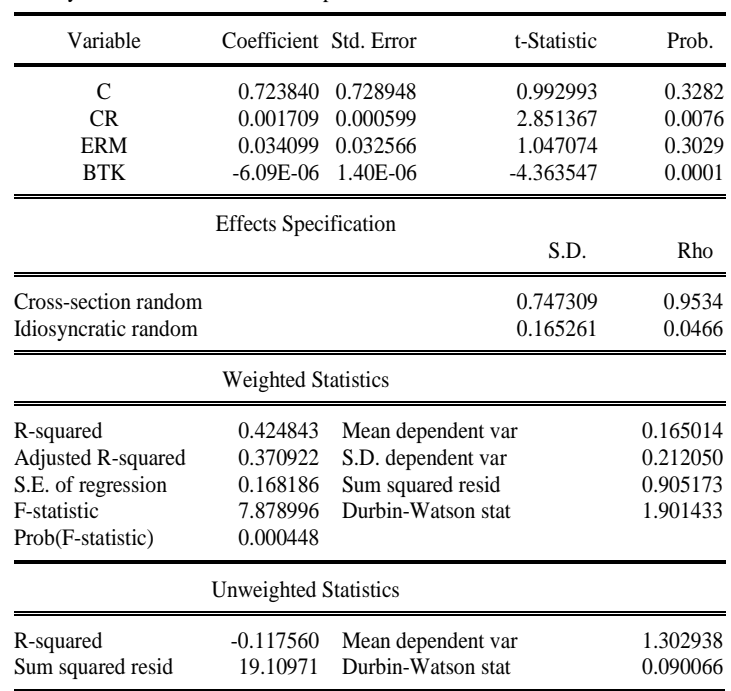

Sumber : Hasil Olahan Data Eviews 10

Berdasarkan tabel 4.8 diatas menunjukan model persamaan regresi data panel dengan hasil estimasi Random Effect Model (REM) sebagai berikut :
Financial Distress $(\mathrm{FD})=0.723840+0.001709$

$(\mathrm{CR})+0.034099(\mathrm{ERM})+-6.09 \mathrm{E}-06(\mathrm{BTK})+$ 0.728948

\section{Uji Hipotesis}

\section{Uji Parsial (Uji t)}

Berdasarkan hasil uji regresi data panel REM dipeoleh output hasil uji $t$ adalah sebagai berikut :

Tabel 4.9

Hasil Uji t

\begin{tabular}{ccccl}
\hline \hline Variable & t- tabel & t-Statistic & Prob. & Kesimpulan \\
\hline \hline CR & 1,69389 & 2.851367 & 0.0076 & Berpengaruh \\
ERM & 1,69389 & 1.047074 & 0.3029 & Tidak Berpengaruh \\
BTK & 1,69389 & -4.363547 & 0.0001 & Berpengaruh \\
\hline \hline
\end{tabular}

Sumber : Hasil Olahan Data Eviews 10

\section{Uji Simultan (Uji F)}

Berdasarkan hasil pada tabel 4.8, hasil dari perhitungan dengan menggunakan uji FStatistic atau $F_{\text {hitung }}$ menunjukkan nilai sebesar 7.878996 lebih besar dari $F_{\text {tabel }}$ 2,90, hasil tersebut menunjukkan bahwa Current Ratio (CR), Enterprise Risk Management (ERM), dan Biaya Tenaga Kerja (BTK) secara bersamasama (simultan) berpengaruh dalam memprediksi Financial Distress (FD).

\section{Koefisien Determinasi}

Uji Koefisien Determinasi (Adj $R^{2}$ ) digunakan untuk mengukur seberapa besar kombinasi variabel independen secara bersama-sama mempengaruhi variabel dependen dengan mempertimbangkan jumlah sampel data dan jumlah variabel yang digunakan. Nilai Adj $\mathrm{R}^{2}$ adalah diantara 0 sampai $1\left(0 \leq \mathrm{R}^{2} \geq 1\right)$. Berdasarkan tabel 4.8 menunjukkan nilai Adj $\mathrm{R}^{2}$ sebesar 0.370922 yang berarti bahwa kemampuan variabel independen Current Ratio (CR), Enterprise Risk Management (ERM), dan Biaya Tenaga Kerja (BTK) dalam menjelaskan Financial Distress adalah sebesar 37\%, sisanya sebesar $63 \%$ dijelaskan oleh variabel lain yang tidak dijelaskan dalam penelitian ini.

\section{Pengaruh Current Ratio (CR) Dalam Memprediksi Financial Distress (FD)}

Berdasarkan hasil penelitian ini, membuktikan bahwa ketika Current Ratio (CR) di perusahaan sektor tekstil dan garment mengalami kenaikan, maka nilai dari Z-Score 
semakin meningkat, begitu juga sebaliknya. Ketika nilai Z-Score meningkat, kemungkinan perusahaan mengalami Financial Distress semakin rendah. Contohnya, pada PT Pan Brothers Tbk nilai dari Current Ratio setiap tahunnya mengalami kenaikan, maka nilai dari Z-Score semakin meningkat juga setiap tahunnya. Sedangkan pada perusahaan Eratex Djaja TBk nilai dari Current Ratio setiap tahunnya menagalami penurunan, maka nilai dari Z-Score nya semakin turun juga. Hasil ini sesuai dengan penelitian yang dilakukan oleh Imam Asfali (2019) yang menyatakan bahwa Current Ratio (CR) berpengaruh positif dan signifikan terhadap Financial Distress (FD)

\section{Pengaruh Enterprise Risk Management (ERM) Dalam Memprediksi Financial Distress (FD)}

Berdasarkan penelitian ini, membuktikan bahwa persentase pengungkapan Enterprise Risk Management (ERM) tidak berpengaruh dalam memprediksi Financial Distress (FD). Karena, pengungkapan Enterprise Risk Management (ERM) masih dipandang oleh perusahaan hanya untuk mengikuti peraturan yang sudah ada dan belum memiliki hubungan langsung dengan kondisi Financial Distress pada suatu perusahaan. Contohnya, persentase pengungkapan Enterprise Risk Management tertinggi dimiliki oleh PT Sri Rejeki Isman Tbk, tetapi hal tersebut tidak mempengaruhi nilai dari Z-Score. Hasil ini sesuai dengan penelitian yang dilakukan oleh Arya Imamuddin Koeswara (2016) yang menyatakan bahwa Enterprise Risk Management (ERM) tidak berpengaruh pada kondisi Financial Distress.

\section{Pengaruh Biaya Tenaga Kerja (BTK) Dalam Memprediksi Financial Distress (FD)}

Salah satu indikasi terjadinya Financial Distress pada suatu perusahaan, yaitu tingginya tingkat perputaran karyawan. Tingginya tingkat perputaran karyawan dapat disebabkan oleh perusahaan yang tidak memberikan gaji/upah yang sesuai dengan kemampuan pekerja. Hal tersebut dapat menyebabkan bahwa perusahaan sedang mengalami kondisi Financial Distress. Biaya Tenaga Kerja merupakan salah satu faktor yang cukup penting dalam menunjang kegiatan yang berhubungan dengan faktor produksi. Berdasarkan penelitian ini, membuktikan bahwa ketika Biaya Tenaga Kerja (BTK) semakin tinggi, maka nilai dari ZScore semakin rendah, begitu juga sebaliknya.
Ketika nilai Z-Score rendah, kemungkinan perusahaan mengalami Financial Distress semakin tinggi. Karena, perusahaan harus menanggung beban biaya tenaga kerja yang cukup tinggi. Contohnya, PT Asia Pasific Investama Tbk nilai dari Biaya Tenaga Kerja setiap tahunnya mengalami kenaikan, maka nilai dari Z-Score semakin turun juga setiap tahunnya. Sedangkan pada perusahaan Nusantara Inti Corpora TBk nilai dari Biaya Tenaga Kerja setiap tahunnya menagalami penurunan, maka nilai dari Z-Score nya semakin meningkat juga setiap tahunnya. Hasil ini sesuai dengan penelitian yang dilakukan oleh Dean Subhan Saleh. SE.,MM (2018) yang menyatakan bahwa Biaya Variabel berpengaruh secara signifikan dalam memprediksi Financial Distress (FD).

\section{KESIMPULAN}

\section{Kesimpulan}

a) Berdasarkan hasil penelitian dan pembahasan mengenai Current Ratio, Enterprise Risk Management, dan Biaya Tenaga Kerja Dalam Memprediksi Financial Distress Pada Perusahaan Sektor Tekstil Dan Garment Yang Terdaftar Di Bursa Efek Indonesia Tahun 2016-2018.

b) Current Ratio (CR) berpengaruh positif signifikan terhadap nilai Z-score. Hal ini menggambarkan bahwa jika Current Ratio (CR) mengalami kenaikan sebesar satu satuan maka semakin meningkat nilai ZScore yang artinya Financial Distress (FD) akan semakin rendah.

c) Persentase pengungkapan Enterprise Risk Management (ERM) tidak berpengaruh signifikan terhadap nilai Z-score. Artinya meskipun persentase pengungkapan Enterprise Risk Management (ERM) semakin besar ataupun semakin kecil hal tersebut tidak akan berpengaruh dalam memprediksi Financial Distress (FD).

d) Biaya Tenaga Kerja (BTK) berpengaruh negatif signifikan terhadap nilai Z-score. Hal ini menggambarkan bahwa semakin tinggi Biaya Tenaga Kerja (BTK), maka semakin rendah nilai Z-Score yang artinya Financial Distress (FD) akan semakin tinggi.

e) Current Ratio, Enterprise Risk Management, dan Biaya Tenaga Kerja bersama-sama secara (stimultan) 
berpengaruh positif dalam memprediksi Financial Distress Pada Perusahaan Sektor Tekstil Dan Garment Yang Terdaftar Di Bursa Efek Indonesia Tahun 2016-2018.

\section{Saran}

Disarankan agar dapat memberikan informasi bagi perusahaan tentang pertimbangan dalam menentukan langkah untuk memprediksi Financial Distress. Dengan melakukan :

a) Disarankan bagi perusahaan untuk mempertahankan nilai dari Current Ratio.

b) Disarankan bagi perusahaan untuk meningkatkan persentase pengungkapan Enterprise Risk Management.

c) Disarankan bagi perusahaan untuk memperbaiki nilai dari Biaya Tenaga Kerja.

\section{REFERENSI}

Undang-Undang Republik Indonesia No 64 Tahun 2017. Penjelasan UU Tentang Ketentuan Impor Tekstil Dan Produk Tekstil. Jakarta : Menteri Perdagangan Republik Indonesia.

Ali, Egi Fajar Nur (2016). Panel Data Analysis Using Eviews. Selft Published Ebook.

Fahmi, Irham. 2015. Manajemen Perbankan Konvensional dan Syariah. Jakarta : Mitra Wacana Media.

Ghozali, Imam. 2016. Aplikasi Analisis Multivariete Dengan Program IBM SPSS 23. Semarang : Badan Penerbit Universitas Diponegoro.

Kasmir. 2012. Analisis Laporan Keuangan. Jakarta : PT. Raja Grafindo Persada.

Sugiyono. 2017. Metode Penelitian Bisnis (Pendekatan Kuantitatif, Kualitatif dan $R \& D)$. Edisi 21. Bandung: CV. Alfabeta.

Dean Subhan Saleh. SE., MM, 2018. "Pengaruh Operating Capacity, Arus Kas Operasi Dan Biaya Variabel Terhadap Financial Distress Pada Perusahaan Manufaktur Subsektor Textil Dan Garment Yang Terdaftar Di Bursa Efek Indonesia (BEI) Tahun 2009-2016" dalam Jurnal Ekonomi dan Bisnis. 2018. STIE Dr KHEZ Muttaqien : Jurnal Ekonomi dan Bisnis.
Dekeng Setyo Budiarto dan Atika Anisaulfitria Putuyana, 2018. "Pengungkapan Enterprise Risk Management Dan Intellectual Capital: Apakah Bermanfaat Bagi Perusahaan Real Estate?" dalam Jurnal Ustjogja.ac.id. 2018. Universitas PGRI Yogyakarta : Jurnal Ustjogja.ac.id.

Devi Sunitha, I Dewa Nyoman Badera dan I Gusti Ayu Nyoman Budiasih, 2017. "Pengaruh Enterprise Risk Management Disclosure Dan Intellectual Capital Disclosure Pada Nilai Perusahaan" dalam Jurnal Akuntansi dan Keuangan Indonesia.

Dimas Priambodo, 2017. Analisis Perbandingan Model Altman, Springate, Grover Dan Jmizewski Dalam Memprediksi Financial Distress Pada Perusahaan Sektor Pertambangan Yang Terdaftar di Bursa Efek Indonesia Periode 2012-2015 Skripsi Fakultas Ekonomi Universitas Negeri Yogyakarta : Diterbitkan.

Edy dan May Tania, 2018. "Ketepatan Model Altman, Springate, Zmijewski, dan Grover Dalam Memprediksi Financial Distresss" dalam Jurnal Reviu Akuntansi dan Keuangan.

Febriyan dan Ari Hadi Prasetyo, 2019. "Pengaruh Kas operasi, Likuiditas, Leverage, Diversifikasi, dan Ukuran Perusahaan Terhadap Financial Distress Pada Perusahaan Sektor Aneka Industri yang Terdaftar di Bursa Efek Indonesia 2014-2016" dalam Jurnal Akuntansi. 2019. Jakarta : Jurnal Akuntansi.

Frizka Fadilla dan Vaya Juliana Dillak, S.E., M.M. 2019. "Pengaruh Struktur Modal, Pertumbuhan Perusahaan Dan Profitabilitas Terhadap Financial Distress Pada Perusahaan Manufaktur Food and Beverage Yang Terdaftar Di Bursa Efek Indonesia Periode 2014-2017' dalam Jurnal e-Proceeding of Management. 2019. Universitas Telkom : Jurnal eProceeding of Management.

Hikmah Amalia. 2018. Pengaruh Current Ratio, Debt To Equity Ratio, Earning Per Share, Return On Asset Terhadap Dividend Payout Ratio Pada Perusahaan Yang Tergabung Dalam Daftar Efek Syariah Sektor Aneka Industri Periode 
2013-2017. Skripsi Sekolah Tinggi Ilmu Ekonomi (STIE) DR. KHEZ. MUTTAQIEN : tidak diterbitkan.

Imam Asfali, 2019. "Pengaruh Profitabilitas, Likuiditas, Leverage, Aktivitas, Pertumbuhan Penjualan Terhadap Financial Distress Perusahaan Kimia" dalam Jurnal Ekonomi dan Manajemen. 2019. Universitas Gajayana Malang : Jurnal Ekonomi dan Manajemen.

Indah Permata. 2018. Analisis Potensi Kebangkrutan Perusahaan Menggunakan Metode Altman Z-Score Pada Perusahaan Transportasi Yang Terdaftar Di Bursa Efek Indonesia Periode 2012-2016. Skripsi Fakultas Ekonomi Dan Bisnis Universitas Lampung Bandung : diterbitkan.

Layna Lutfiani. 2019. Pengaruh Biaya Tenaga Kerja Langsung Dan Biaya Bahan Baku Terhadap Laba Bruto Konvekssi Aba Collection TulungAgung. Skripsi Fakultas Ekonomi Dan Bisnis Islam Institut Agama Islam Negeri Tulung Agung : diterbitkan.

Muhammad Iksan Sopian, Erry Sunarya dan Kokom Komariah, 2019. "Analisis Kemampuan Rasio Likuiditas dan Profitabilitas Dalam Mengukur Financial Distress" dalam Journal of Economic, Business and Accounting. 2019. Universitas Muhammadiyah Sukabumi : Journal of Economic, Business and Accounting.

Mutiara Adawiyah. 2019. Analisis Perbandingan Model Grover, Model Zmijewski, Model Springate Dan Model Ohlson Dalam Memprediksi Financial Distress Pada Perusahaan BUMN Dan Anaka Perusahaan BUMN Yang Terdaftar Di Bursa Efek Indonesia Tahun 20142018. Skripsi Fakultas Ekonomi Dan Bisnis Universitas Pasundan Bandung : diterbitkan.

Nolita Yeni Siregar dan Tiara Amelia Safitri, 2019. "Pengaruh Pengungkapan Enterprise Risk Management, Intellectual Capital, Corporate Social Responbility Dan Sustainability Report Terhadap Nilai Perusahaan" dalam Jurnal Bisnis Darmajaya. 2019. Bandar Lampung : Jurnal Bisnis Darmajaya.
Rachel Adinda Oktavia dan Yuyun Isbanah, 2019. "Pengungkapan Enterprise Risk Management Pada Bank Konvensional Di Bursa Efek Indonesia" dalam Jurnal Ilmu Manajemen. 2019. Surabaya : Jurnal Ilmu Manajemen.

Rosy Pratiwi, 2019. Pengaruh Capital Expenditure Dan Biaya Tenaga Kerja Terhadap Indikasi Financial Distress Dengan Kualitas Laba Sebagai Variabel Moderasi Pada Perusahaan Subsektor Telekomunikasi Yang Terdaftar Di Bursa Efek 